\title{
Analysis Of Intellectual Capital Management Success Through The Improvement Of Micro, Small, And Medium Enterprise (MSME) Performance On Food And Beverages In Kudus Regency
}

\author{
Zuliyati $^{1}$, Zamrud Mirah Delima ${ }^{2}$ \\ \{zuliyati@umk.ac.id ${ }^{1}$, mirah.delima@umk.ac.id² $\}$ \\ Universitas Muria Kudus, PO Box 53, Bae, Kudus ${ }^{12}$
}

\begin{abstract}
The aim of this study is to examine empirically and analyze whether technology management success which is proxied by Intellectual Capital has the influence toward MSME performance. Individual knowledge must be managed in order to get knowledge of MSME, which eventually becomes intellectual capital as the intangible asset (intangible assets) owned by MSME, thus the performance of MSME becomes more optimal. The variables of this study are the performance of MSME as the dependent variable, while the independent variable is Intellectual Capital with the proxy of human capital, structural capital and customer capital. The object of this research is MSME in Kudus Regency which is engaged in food and beverage. The research method used multiple linear regression analysis. The results of human capital research, structural capital and customer capital have a significant positive effect on MSME performance.
\end{abstract}

Keywords: Intellectual capital, human capital, structural capital, customer capital, MSME performance, multiple linear regression.

\section{Introduction}

Globalization, technological innovation and stringent business competition force companies to change their ways to do the business in this century. Business activities are growing along by the discovery of various technologies in producing goods and services, not apart from the businesses which engaged in the field of food and beverages. In order companies to survive, companies must rapidly change their strategy from conventional business based on labor business to knowledge business that focuses on technology. Hence the main characteristic of the company becomes a company based on science and technology. Along with economic changes that characterized by economy based on science and technology. Under the application of knowledge and technology management, the prosperity of a company will depend on the creation of transformation and capitalization of the knowledge and technology itself. Technology management is able to be realized in the form of human resource capabilities within using machine-based equipment, management of modern management and the ability of employees to operate various automation-based software and hardware. It is commonly referred to as human capital. The method of work completion which is not anymore manual, production manner, and also equipment or machine that used in a production process is structural capital in technological management where exist in MSME.

ICCSET 2018, October 25-26, Kudus, Indonesia

Copyright () 2018 EAI

DOI 10.4108/eai.24-10-2018.2280528 
No less important is the management of technology within relation with customers such as online marketing systems, promoting with web or the internet and building networks with stake holders. That case is a customer capital which needs to be managed by the proper technology. The management of technology is the management of intangible assets that must be managed well by MSME till performance increases.

Micro, Small and Medium Enterprises (MSMEs) have a strategic role in national economic development, because in addition to playing a role in economic growth and employment, they also playing a role in the distribution of development results. MSME needs to prepare themselves to be able to compete both in comparative and competitive advantage. Increasing economic development to improve the competitiveness of MSMEs depends on the effectiveness of technology and science management and technology. As for technology and science and technology are made of the individual knowledge that must be organized in order to become the knowledge of company, which eventually knowledge becomes intangible assets by MSME. This knowledge belongs to intellectual capital which is able to take the form of: experience, textual information, and opinions of the experts in their fields. Hence MSME company will be sustainable if it uses that information or experience to create MSME competency [1].

Diminishing dependency of Kudus society on large businesses especially cigarettes, encourages the emergence of MSMEs engaged foods and beverages. If the big business grows, it will only lead Kudus society to become "labor" and if MSMEs grow more, it can encourage Kudus people to make big as "entrepreneurs" and it is believed to be more guarantee the distribution of GRDP. The "Gusjigang" Bagus, Ngaji and Dagang philosophy of Kudus people where Kudus is famous with "Cigarette City" will align Kudus as "Jenang City" and "Soto City". MSME with its flexible characteristics and application of mixed program between capital and labor intensive are able to utilize the existing resources (local), so as afford to survive the economic crisis and the changes that occur as the consequence of globalization. A new stream of competitive advantage analysis is known as the ResourceBased View of the firm (RBV). This value is relevant within context of strong economy characterized by the superiority of science and technology and technology or an economy that relies on intangible assets. MSMEs which are able to compete, have competitive advantage and get comparability always try to find competitive strategies and the right competitiveness to win. The concept of strategy will make MSME to perform high and excel in the field of business.

The relationship between intellectual capital and the company's financial performance has been proven empirically by several studies. [2] stated that there is a positive relationship between the disclosure of Intellectual Capital and market capitalization on 53 companies listed on the Indonesia Stock Exchange. [3] showed that human capital will have a stronger relationship with structural capital if the relationship is direct than indirect with customer capital as the intervening variable. In addition, the research also shows that customer capital and structural capital should functionate as the intervening variables in the relationship between human capital and business performance. While Marr et.al (2004) in [4] structural capital can be used to mediate customer capital relations and business performance. [1] also proves that SMEs have a contribution in employment. It is extremely important for MSMEs to utilize science and technology and technology efficiently and increase the potency to innovate in order to gain the excellence in competition. Thus the management of Intellectual Capital becomes the prime instance for business development in the future. 


\section{Literature Review dan Formulation of Hypothesis}

\subsection{Stakeholder Theory}

The underlying theory of this research is stakeholder theory. Stakeholder theory is more considering the position of stakeholders who are considered powerful. These 'stake' groups, according to Riahi-Belkaoui, include shareholders, employees, customers / customers, suppliers, creditors, the government and the community. This stakeholder group is the major consideration of MSMEs in managing their businesses optimally, thus maximum performance can be achieved by utilization of assets owned including intellectual capital owned by MSMEs. In the view of stakeholder theory, companies have stakeholders, not just shareholders (Riahi-Belkaoui, 2003 in [4]).

The consensus that develops in the context of stakeholder theory is accounting profit is only a measure of return for shareholders, while company value added, customer satisfaction, and employee welfare are more accurate measures created by stakeholders and then distributed to the same stakeholders (Meek and Gray in [4]).

\subsection{Intellectual Capital}

To be able to abuse intellectual capital, companies need to understand what meant by intellectual capital is. Through understanding of these intangible assets, companies can formulate and define strategies and policies to evaluate and establish productivity of their most valuable assets. The idea of intellectual model began in the mid-1980s as indicated by the shift from production based to service into knowledge-based economy (Anatan, 2006).

Some definitions of Intellectual Capital include Smedlund and Poyhen (2005) in [5] described Intellectual Capital as an organizational capability to create, transfer, and implement science and technology and technology. [6] stated that generally, researchers identified three main constructs of Intellectual Capital, namely: human capital (HC), structural capital (SC), and customer capital (CC). According to [6], HC simply represents the individual knowledge stock of an organization represented by its employees. $\mathrm{HC}$ is a combination of genetic inheritance; education; experience, technology and attitude about life and business.

\subsubsection{Human Capital}

Human capital is defined as the knowledge and technology, skills, and experience that employees bring when managing a company. Some of these knowledge and technologies are unique for each individual, and some are general, such as capacity for innovation, creativity, know-how and experience, learning capacity, loyalty, formal education and education (Starovic and Marr, 2004 in [3]).

Human capital includes individual knowledge and technology from an organization that exists in its employees as described by Bontis, Crossan and Hulland, in [3] which is produced through competence, attitudes and intellectual intelligence by Roos, Roos, Edvinsson and Dragonetti, in [3]. Human capital is also a combination of genetic inheritance, education, experience and attitudes about life and business. Human capital which is owned by MSMEs will assist within business management by existing technology. 


\subsubsection{Structure Capital}

Structural capital is defined as the knowledge and technology that will remain in the company. Structural capital consists of organizational routines, procedures, systems, culture, and databases. Some of the structural capital are protected by law and become intellectual property rights, which are legally owned by companies (Starovic and Marr, 2004, as quoted in [3]).

Relate to previous explanation, structural capital has two objectives that must be achieved. Firstly, codify knowledge and technology that can be transferred. This is done thus the system is not lost anyhow.

\subsubsection{Customer Capital}

Intellectual capital is not created from one by one human capital, structural capital, and capital employee. Customer capital or named relational capital includes relationships between customers and partners at national and international levels. The indicator which is used to explain this is "the number of international bodies that have representatives from the OeNB" or "confidence index" that is compiled every three months by an independent agency.

Customer Capital is a harmonious relationship or called an association network owned by the company and its partners, both those who come from reliable and quality suppliers, come from loyal customers and feel satisfied with the services of the company concerned, derived from the company's relationship with the government and with the surrounding community. Customer Capital can arise from various parts outside of the corporate environment that can add value to the company [7].

\subsection{The Correlation between Intelectual Capital and MSME Perfomance in Increasing Competiveness}

MSME performance is the level of success achieved both in quality and quantity from the level of achievement that has been targeted. At present, UMKM is required to optimize intellectual capital (development based on knowledge and technology), hence MSMEs are expected to focus on efforts through intellectual capital. MSMEs could learn how to use a combination of human, structural and relational capital that they have to increase their own capacity to compete in global market world [8]

The points should be done by MSMEs, for example to develop human capital, training and education for their employees are held. Intellectual capital includes not only patents, copyrights, and other forms of intellectual property, but it is a synergy of company knowledge and technology, experience, relationships, processes, inventions, innovations, market presence and community influence. Intellectual capital provides a new model for calculating the true value of an organization that cannot be calculated in traditional financial accounting [9]

MSMEs that are able to create competitive advantage can improve the relationship between intellectual capital and MSME performance. This indicates that the higher value of intellectual capital increasingly, the higher the financial performance (profitability) [10]. To create a unique combination of intellectual capital in Micro, Small and Medium Enterprises (MSMEs) in Indonesia, MSMEs must first improve their low productivity. 


\subsection{Hypothesis}

Formulating the hypothesis in this study is:

Hypothesis 1: Human Capital has the significant positive effect through MSME performance in Kudus regency engaged in foods and beverages.

Hypothesis 2: Structural Capital has the significant positive effect through MSME performance in Kudus regency engaged in foods and beverages.

Hypothesis 3: Customer Capital has the significant positive effect through MSME performance in Kudus regency engaged in foods and beverages.

Now the research model is illustrated in Figure 1 below.

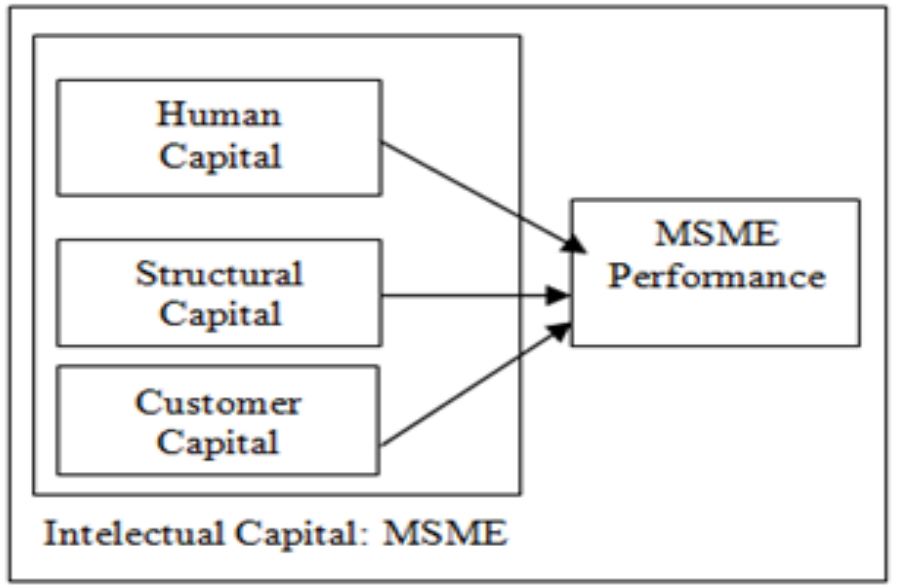

Fig. 1. Research Model.

\section{Research Metodology}

The method which was used to collect the data was primary data by distributing questionnaires to respondents. The population in this study was all MSMEs in Kudus regency. The research sampling technique used random sampling method. By this method, a list of MSMEs in Kudus regency was made, then randomly selected representatives of MSMEs were classified as SMEs engaged in food and beverages that would be sampled. Some of these MSMEs were like performance in making Jenang, bread, food stalls, cafes and the like. These businesses are chosen because food and beverages are booming and preferring by others. Thus, that case needs optimizing the tools in good and proper way. Total sampling of MSMEs calssified an SMEs engaged in food and beverages are 48 respondents. 


\begin{tabular}{|c|c|c|}
\hline \multicolumn{3}{|c|}{ GENDER } \\
\hline MALE & 13 & $27 \%$ \\
\hline FEMALE & 35 & $73 \%$ \\
\hline TOTAL & 48 & $100 \%$ \\
\hline \multicolumn{3}{|c|}{ TYPE BUSSNIES } \\
\hline JENANG & 10 & $21 \%$ \\
\hline BREAD & 5 & $10 \%$ \\
\hline FOOD STALL & 21 & $44 \%$ \\
\hline CAFÉ & 8 & $17 \%$ \\
\hline OTHERS & 4 & $8 \%$ \\
\hline TOTAL & 48 & $100 \%$ \\
\hline
\end{tabular}

Source : Data processed, 2018

Fig. 2. Demography of Respondent table.

\subsection{Research Metodology}

The research data was analyzed by using analyzing techniques which includes: testing instruments involved reliability and validity test, then normality testing was carried out by Kolmogorov Smirnov test. The next step was the classic assumption test, used to determine whether a regression model really showed a significant representative relationship or named BLUE (Best Linear Unbiased Estimator. There are 3 classic assumption tests that must be met before using the regression model, including the following: Test Multicollinearity, Autocorrelation Test and Heteroscedasticity Test)..

The multiple linear regression equation for this study is as follows:

$$
\operatorname{MSMEP}=\alpha+\beta 1 \mathrm{HC}+\beta 2 \mathrm{SC}+\beta 3 \mathrm{CC}+\varepsilon
$$

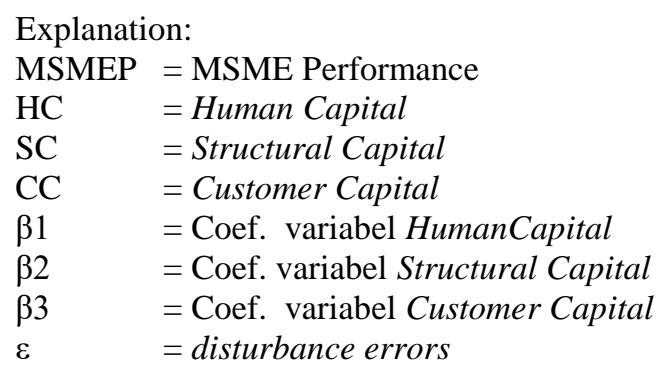

Model feasibility test used: The coefficient of determination to measure the ability of the model in explaining the variation of the dependent variable. Significance Test (Statistical Test F), testing in this way was used to show whether all independent or independent variables included in the model to have a joint effect on the dependent / dependent variable. Dependent [11]. Then Hypothesis Testing (Statistical Test t) was conducted to show how far the influence of one independent variable was in explaining the dependent variable. 


\section{Findings and Discussions}

\subsection{Instrument Test}

The reliability test which was used was the internal consistency reliability test as measured by the Cronbach Alpha coefficient and the results were reliable. Validity test was done by analyzing the correlation between the answers to the question score and the total score. The results of the correlation analysis indicated that there was a significant relationship between the score of the question items and the total score that represented the construct, so this measure was considered valid.

\subsection{Normality Test}

The variable which was used in the Kolmogorov Smirnov test was the residual variable (error term). The sign value was $0.975>0.05$ then the assumption of normality was accepted (can be seen in table 2 below)

\begin{tabular}{|l|l|r|}
\hline \multicolumn{2}{|c|}{ One-Sample Kolmogorov-Smirnov Test } \\
\hline N & \multicolumn{1}{|c|}{ ABS } \\
\hline Normal Parametersa., & Mean & 48 \\
& Std. Deviation & 310979.6667 \\
\hline MostExtreme Differences & Absolute & 42195.34623 \\
& Positive & .141 \\
& Negative & .068 \\
\hline Kolmogorov-Smirnov Z & & .141 \\
\hline Asymp. Sig. (2-tailed) & & .975 \\
\hline a. Test distribution is Normal. & \\
\hline b. Calculated from data. & & .297 \\
\hline
\end{tabular}

Source : Data processed, 2018

Fig. 3. Normality Test Table.

\subsection{Classic Assumption Test}

\subsubsection{Multicollinearity Test}

Test results could be seen with VIF values. The results of a VIF were not more than 10 and the tolerence value was not less than 0.1 , then the model could be said to be free of multicollinearity. Multicollinearity test results were able to be seen in table 3 below. 


\begin{tabular}{|c|c|c|c|}
\hline \multicolumn{4}{|c|}{ Coefficients ${ }^{3}$} \\
\hline \multirow{2}{*}{\multicolumn{2}{|c|}{ Model }} & \multicolumn{2}{|c|}{ Collinearity Statistics } \\
\hline & & Tolerance & VIF \\
\hline \multirow[t]{3}{*}{1} & $\mathrm{x} 1$ & .731 & 1.367 \\
\hline & $\times 2$ & .600 & 1.667 \\
\hline & $\times 3$ & .597 & 1.676 \\
\hline
\end{tabular}

Source: Data processed, 2018

Fig. 4. Multicollinearity Test Table.

\subsubsection{Autocorrelation Test}

Autocorrelation is a correlation between members of a series of observations sorted by time or space. The autocorrelation assumption was tested using the Durbin Watson test in table 4 of 0.986 and showed no autocoleration.

\subsubsection{Heteroscedasticity Test}

Heteroscedasticity test is intended to test whether in the regression model there is a residual variance inequality one observation to another observation. A good regression model is homokedasticity or heteroscedasticity does not occur [11]. The significance value was 0.297 greater than alpha 0.05 , so there was no heteroscedasticity.

\subsection{Multiple Linear Regression Analysis}

Hypothesis testing was done by using Multiple Regression Analysis and SPSS. The results of the test could be seen in table 4 below.

\begin{tabular}{|c|c|c|c|c|c|c|}
\hline \multicolumn{7}{|c|}{ Coefficients $^{8}$} \\
\hline \multirow{2}{*}{\multicolumn{2}{|c|}{ Model }} & \multicolumn{2}{|c|}{ Unstandardized Coefficients } & \multirow{2}{*}{$\begin{array}{c}\text { Standardized } \\
\text { Coefficients }\end{array}$} & \multirow[b]{2}{*}{$t$} & \multirow[b]{2}{*}{ Sig. } \\
\hline & & $B$ & Std. Error & & & \\
\hline \multirow[t]{4}{*}{1} & (Constant) & 20.214 & 7.708 & & 2.623 & .012 \\
\hline & $x 1$ & .070 & .099 & .107 & 2.706 & .001 \\
\hline & $x_{2}$ & .067 & .118 & .095 & 2.566 & .004 \\
\hline & X3 & .298 & 098 & .510 & 3.045 & .004 \\
\hline
\end{tabular}

Source : Data processed, 2018 
Fig. 5. Multiple Linear Regression Table.

The regression equation for this study is as follows:

$$
\mathrm{MSMEP}=20,214+0,70 \mathrm{HC}+0,067 \mathrm{SC}+0,298 \mathrm{CC}+\varepsilon
$$

$$
\begin{array}{ll}
\text { Explanation } & \\
\text { MSMEP } & =\text { MSME Performance } \\
\text { HC } & =\text { Human Capital } \\
\text { SC } & =\text { Structural Capital } \\
\text { CC } & =\text { Customer Capital } \\
\varepsilon & =\text { disturbance errors }
\end{array}
$$

\subsection{Goodness of fit Model}

\subsubsection{Determination Coeffision}

The value of Adjusted R2 was 0.214. It was meant that the independent variable could explain the variation of the dependent variable by $21.4 \%$ and the rest was explained by other variables.

\begin{tabular}{|l|l|r|r|r|r|}
\hline \multicolumn{7}{|c|}{ Model Summary $^{\circ}$} \\
\hline Model & \multicolumn{1}{|c|}{$R$} & $R$ Square & $\begin{array}{c}\text { Adjusted } R \\
\text { Square }\end{array}$ & $\begin{array}{c}\text { Std. Error of the } \\
\text { Estimate }\end{array}$ & Durbin-Watson \\
\hline 1 & $.514^{3}$ & .264 & .214 & 2.158 & 1.986 \\
\hline a. Predictors: (Constant), X3, X1, X2 \\
\hline b. DependentVariable: $Y$ \\
\hline \multicolumn{7}{|c|}{ Source : Data processed, 2018} \\
\hline
\end{tabular}

Fig. 6. Determination Coefision Test.

\subsubsection{Significancy Test (Statistic F Test)}

The sig value of 0.003 was below 0.005 and told that all the independent or free variables included in the model effect on the dependent / dependent variable. It could be seen in table 5 below. 


\begin{tabular}{|c|c|c|c|c|c|c|}
\hline \multicolumn{7}{|c|}{ ANOVA ${ }^{\circ}$} \\
\hline \multicolumn{2}{|c|}{ Model } & Sum of Squares & $d f$ & Mean Square & $\mathrm{F}$ & Sig. \\
\hline \multirow[t]{3}{*}{1} & Regression & 73.455 & 3 & 24.485 & 5.259 & $.003^{3}$ \\
\hline & Residual & 204.857 & 44 & 4.656 & & \\
\hline & Total & 278.312 & 47] & & & \\
\hline \multicolumn{7}{|c|}{ a. Predicticos: (Constant), X3, X1,X2 } \\
\hline \multicolumn{7}{|c|}{ b. Dependent Variable:Y } \\
\hline
\end{tabular}

Fig. 7. Statistic F Test.

\subsubsection{Hypothesis Test (Statistic t Test)}

\subsubsection{The Influence of Human Capital through Performance}

Hypothesis 1 : Human Capital had a significant positive effect on the performance of MSMEs in Kudus Regency which was engaged in services, accepted. This could be seen from the test results in table 3 showed the significance value below 0.05 that was equal to 0.01 and the $t$ value was 2.706

Human Capital is an intellectual property owned by a company in the form of knowledge and technology and technology owned by its employees. Human Capital assessment can be seen from the intellectual, expertise, creativity, way of working and the weaknesses of the UMKM employees in using the technology that is owned by MSMEs. To be able to use technology, for example machines in the processing of food and beverages, business owners need to provide training to their employees. The results of the research showed that business owners paid full attention to the capabilities possessed by employees in the business as their collective business capabilities. So that MSMEs capability increased business income, profit and ROA. In addition, by having well-managed human capital, the ability of human resources in using technology makes MSME was able to compete in the industry and be able to respond business activities into competitors.

The results of the research are in accordance with the results of [7] and [3], who stated that human capital has a significant influence on the performance of the company.

\subsubsection{The Influence of Structural Capital towards Performance}

Hypothesis 2 : Structural Capital got a significant positive effect on the performance of MSMEs in Kudus Regency which were engaged in services was accepted. This could be seen by the test results in table 3 . It showed the significance value below 0.05 , that was equal to 0.004 and the $t$ value was 2.566 . 
Structural Capital is the company's ability to fulfill the company's routine process and its structure that supports employees' efforts to produce optimal intellectual performance, as well as overall business performance. The results of the study showed that MSME operational system, manufacturing system, MSME culture, management philosophy, and all Intellectual properties owned by the company had been managed optimally by business owners. Business owners had business ability to meet market needs, thus MSME was capable to increasing business income, profit and ROA. In addition, having well-managed structural capital, MSMEs were able to compete in industry and respond business activities to the competitors. New ideas are needed through innovation with a touch of technology in order to be accepted by market.

The results of the research are in accordance with the results of [12] and [3], who stated that Structural capital has a significant influence on the performance of the company. [6] also stated that structural capital is a critical link that allows intellectual capital to be measured at the level of organizational analysis.

\subsubsection{The Influence of Customer Capital towards Performance}

Hypothesis 3 : Customer Capital influences significant positive effect towards MSME performance in Kudus regency which concerns in accepted-service field. This point could be seen by testing result in table 3 . It evidenced the signifince under 0.05 , it was $0 / 04$ and the highest one was 3.045 .

Customer Capital is a harmonious relationship between the company and its loyal customers and satisfied with the service of the company concerned, as well as all external relations with consumers. The result of the research represented that MSME was able to fulfill customer desires, hence customer satisfaction and customer loyalty were fulfilled. This made customers always became loyal and would always be loyal to the company. Loyalty of customers would be able to increase business income, profit and ROA. In addition, by having a well managed customer capital, MSME might compete in industry and be able to respond the business activities into competitors.

The results of the research are in accordance with the results of [6] and [7], who stated that customer capital has a significant influence on the performance of the company.

\section{Conclusion}

Of the findings and discussions pointed that the management of technology through intellectual capital management had a positive and significant influence on the performance of MSMEs. MSMEs which were able to manage their technology well through optimal management of human capital, good structural capital management and extensive customer capital in the manner of internet. The hypothesis proposed that human capital, structural capital and customer capital have a positive and significant effect, are accepted. As better management of intellectual capital that is owned by MSMEs with the support of existing technology, the more performance is obtained by MSMEs to increase in income, an increasingly effective and efficient production system and the extent of marketing networks so that the value of the company will increase. 


\section{Suggestion}

Based on the results of the study, researchers suggest to expand the object of research by not only researching MSMEs engaged in food and beverages, but it is also recommended for MSMEs engaged in food and beverages to increase the use of technology through appropriate intellectual capital management, thus company performance can more increase and rise.

\section{References}

[1] B. Soetiarso, "Pengelolaan Pengetahuan (Knowledge-Management) Dan Modal Intelektual (Intellectual Capital) Untuk Pemberdayaan UKM," in Konferensi Nasional Teknologi Informasi \& Komunikasi untuk Indonesia, 2006, pp. 187-192.

[2] M. J. Abdolmohammadi, "Intellectual capital disclosure and market capitalization,” J. Intellect. Cap., vol. 6, no. 3, pp. 397-416, 2005.

[3] P. D. Astuti and A. Sabeni, "Hubungan Intellectual Capital Dan Business Performance Dengan Diamond Spesification: Sebuah Perspektif Akuntansi," Semin. Nas. Akunt. VIII, pp. 694-707, 2005.

[4] I. Ulum, "Intellectual Capital Performance of Indonesian," J. Akunt. Keuang. FE-UK Petra Surabaya, 2010.

[5] N. Rupidara, "Intellectual Capital dan Strategi Pengembangan Organisasi dan sumber daya Manusia," 2008.

[6] N. Bontis, "National intellectual capital index: The benchmarking of Arab countries," in Intellectual Capital for Communities: Nations, Regions, and Cities, 2012.

[7] Zuliyati, N. A. Budiman, and Z. M. Delima, "Pengaruh Intellectual Capital Terhadap Kinerja Umkm (Studi Kasus Pada Umkm Di Kabupaten Kudus),” J. Akunt. dan Keuang., vol. 6, no. 2, 2017.

[8] K. Mertins, M. Will, and C. Meyer, "A Consistent Assesment of Intellectual Capital in SMEs InCas: Intellectual Capital Statement-Made in Europe," Electron. J. Knowl. Manag., vol. 5, no. 4, pp. 427-436, 2007.

[9] S. Fathi, S. Farahmand, and M. Khorasani, "Impact of Intellectual Capital on Financial Performance,” Int. J. Acad. Res. Econ. Manag. Sci., vol. 2, no. 1, 2013.

[10] C. H. A. SHIDDIQ and E. N. A. YUYETTA, "PENGARUH MODAL INTELEKTUAL TERHADAP KINERJA KEUANGAN PERUSAHAAN DENGAN KEUNGGULAN KOMPETITIF SEBAGAI VARIABEL INTERVENING (Studi empiris pada perusahaan manufaktur yang terdaftar di Bursa Efek Indonesia tahun 2009-2011)," Universitas Diponegoro, 2013.

[11] I. Ghozali, Aplikasi Analisis Multivariatte, 8th ed. Semarang: Badan Penerbitan Universitas Diponegoro, 2016.

[12] Z. M. Delima and Zuliyati, "Pengaruh Intellectual Capital Terhadap Bussines Performance UMKM Di Kabupaten Kudus,” J. Bingkai Ekon., vol. 3, no. 1, pp. 43-49, 2018. 